Per Anderhag är lektor på Stockholm stads utbildningsförvaltning och affilierad forskare vid institutionen för matematikämnets och naturvetenskapsämnenas didaktik, Stockholms universitet. Per leder det ämnesdidaktiska nätverket i naturvetenskap och teknik vid Stockholm Teaching \& Learning Studies (STLS).

Madeleine Björn är grundskollärare årskurs 1-3 i Stockholms stad. Hon undervisar i alla ämnen men har ett stort intresse för matematik- och teknikämnet samt de naturvetenskapliga ämnena. Madeleine initierade programmeringsarbetet på sin skola för sex år sedan, ett arbete som hela tiden utvecklas.

Birgit Fahrman är universitetsadjunkt och doktorand vid Kungliga Tekniska högskolan inom teknikdidaktik. Hon är behörig ämneslärare i matematik och teknik för grundskolans årskurs 4-9. Hon deltar som koordinator vid Stockholm Teaching \& Learning Studies (STLS).

Annika Lundholm-Bergström är förstelärare i NV-/teknikämnet och arbetar som grundskollärare i årskurs 1-3 i Stockholm stad. Annika initierade programmeringsarbetet på sin skola för sex år sedan, ett arbete som hela tiden utvecklas.

Maria Weiland är grundskollärare Ma/NV och Teknik årskurs 1-7, har licputerat i didaktik vid Uppsala universitet och arbetar som utvecklingslärare i Södertälje kommun.

Tove Wållberg är grundskollärare Ma/NV och Teknik årskurs 1-7. Hon arbetar som förstelärare i Nacka kommun, där hon undervisar i årskurs 4-6.

\title{
PER ANDERHAG
}

Institutionen för matematikämnets och naturvetenskapsämnenas didaktik, Stockholms universitet, Sverige per.anderhag@mnd.su.se

\section{MADELEINE BJÖRN}

Utbildningsförvaltningen, Stockholms stad, Sverige

madeleine.bjorn@edu.stockholm.se

\section{BIRGIT FAHRMAN}

Institutionen för Lärande, Kungliga Tekniska högskolan, Sverige

birgitf@kth.se

\section{ANNIKA LUNDHOLM-BERGSTRÖM}

Utbildningsförvaltningen, Stockholms stad, Sverige

annika.lundholm-bergstrom@edu.stockholm.se

\section{MARIA WEILAND}

Utbildningskontoret, Södertälje kommun, Sverige

maria.weiland@sodertalje.se

\section{TOVE WÅLLBERG}

Välfärd skola, Nacka kommun, Sverige

tove.wallberg@nacka.se

\section{Kod som teknisk lösning: en studie om grundskole- elevers uppfattningar av ändamålsenlighet i deras spontana programspråk}

Studien är genomförd inom ramen för Stockholm Teaching \& Learning Studies 


\section{Abstract}

This study examines primary school students' perception of functionality in their spontaneous programming language for controlling a simple robot. Classroom activities were designed in order to create opportunities for the students (year 1 and year 4) to discuss and develop together with their teachers a shared programming language for controlling a simple robot. The students spontaneously used (a) natural language, (b) images or (c) symbols when they created their programming language. The findings show that the students primarily perceived a code's functionality as a question of readability, rather than how well it fit the purpose of controlling the robot. Possible consequences of the findings for teaching in technology education are discussed.

\section{INLEDNING}

Under en relativt kort tidsperiod har programmering blivit ett inslag i flera länders läroplaner (Balanskat \& Engelhardt, 2015). Införandet har föregåtts av diskussioner där olika intressenter har beskrivit programmering som en nödvändig färdighet i en digital samtid. I dessa diskussioner har olika varianter av demokratiska, epistemologiska och ekonomiska argument lyfts fram; exempelvis arbetsmarknadens behov av programmerare och utveckling av kognitiva förmågor när man programmerar (Clear, 2015). Liknande argument har lyfts vid tidigare läroplansrevideringar och under 80-talet var programmering också ett inslag i den svenska grundskolans matematikämne (Rolandsson, 2015). Sedan 2018 är programmering återigen en del i den svenska grundskolans läroplan. I läroplanens inledande kapitel, som samtliga skolans ämnen ska förhålla sig till, och i relation till samhällskunskapsämnet är kunskap om programmeringens betydelse i samhället framskrivet som en form av medborgarfärdighet (Skolverket, 2018). I teknikämnets, och matematikämnets, -kursplan är programmering framskrivet som ett verktyg att använda i relation till ett ämnesinnehåll.

Kunskapen om undervisning i programmering och konsekvenser för grundskoleelevers lärande är begränsad (Balanskat \& Engelhardt, 2015). Tidigare forskning, som oftast har undersökt undervisning och lärande på högskolenivå, visar dock att det är svårt att lära sig att programmera (Sáez-Lopéz, Román-González, \& Vázquez-Cano, 2016) och speciellt syntax och den logik som förutsätts för att formulera en lösning till ett specifikt problem är svårt för nybörjare (Robins, Rountree \& Rountree, 2003). Olika visuella programmeringsmiljöer har därför utvecklats för att stötta elevers och studenters förståelse för programmeringskoncept och principer (Sorva, 2012; Yukselturk \& Altiok, 2016). Studier av undervisning i visuella programspråk har visat på positiva effekter i relation till mer övergripande förmågor som anses vara relevanta för programmering, som t.ex. problemlösningsförmåga (Sáez-Lopéz, Román-González \& Vázquez-Cano, 2016). Även lärande kring mer specifika begrepp har rapporterats. I Bers, Flannery, Kazakoff och Sullivans (2014) och Zaharijas, Mladenović och Boljats (2013) interventionsstudier noterades vissa positiva förändringar gällande barnens förståelse av begrepp som t.ex. felsökning och sekvensering. Forskare och policyföreträdare har därför intresserat sig för visuella programspråk och programmerbara robotar som möjliga didaktiska redskap.

\section{Programmerbara robotar}

Inom forskningsfältet beskrivs programmerbara robotar som lämpliga verktyg för att introducera programmeringskoncept men också för att utveckla olika förmågor (Green, Wagner \& Green, 2018; Misirli \& Komis, 2014). Det lekbetonade sammanhanget anses fungera motiverande och därmed kunna stödja elevernas lärande (Highfield, 2010; Newhouse, Cooper \& Cordery, 2017). Även på policynivå uppfattas programmerbara leksaker och robotar som lämpliga didaktiska redskap för att undervisa i programmering och i vissa länders läroplaner refereras explicit till programmerbara leksaker (Misirli \& Komis, 2014). Förutom färdigheter i programmering och lärande av specifika programmeringsbegrepp, anses programmerbara robotar stödja elevers sociala och generiska färdigheter som samarbetsförmåga och logiskt tänkande (Bers \& Horn, 2010). Forskning kring yngre barns (6-8 år) lärande har speciellt intresserat sig för de relativt välkända Beebot och Bluebot (Misirli \& Komis, 2014) och t.ex. Beraza, Pina och Demo (2010) argumenterar för deras användbarhet, även om de också menar 
att det finns begränsningar i hur de kan användas i relation till programmering. Beebots:en har endast fem kommandon vilket utgör en begränsning för vilken typ av uppgifter de kan programmeras att utföra (Beraza, Pina \& Demo, 2010; Kazakoff, Sullivan \& Bers, 2013). Trots begränsningarna har Misirli och Komis (2014) visat att Beebots kan stödja elevers spatiala förståelse samt färdigheter i att sekvensera uppgifter och problem. Studier har också visat att Beebots och liknande robotar kan användas i matematikundervisningen och t.ex. Highfield, Mulligan och Hedberg (2008) visade på positiva effekter gällande yngre barns ( 5 respektive 8 år) förståelse för mätande och geometri. I De Michele, Demo och Siegas (2008) studie, programmerade eleverna Beebots genom att använda matematiska begrepp relaterade till multiplikation och addition. Få studier har undersökt relationen mellan programmering och lärande motsvarande det svenska teknikämnet. I en studie av Kurebayashi, Kamada, Kanemune och Kuno (2007) uppvisade elever (11 år) med erfarenhet av programmerbara robotar större förståelse för tekniska system jämfört med en kontrollgrupp där eleverna inte hade programmerat. Författarna föreslår därför att programmering kan vara betydelsefullt för elevers förståelse för teknik i samhället och därmed också för deras tekniska allmänbildning (Kurebayashi, Kamada, Kanemune \& Kuno, 2007).

I några av ovanstående studier introducerar forskarna och lärarna ett programspråk som eleverna använder för att styra Beebotarna. Vanligtvis är programspråket konstruerat som grafiska representationer av robotens kommandon, vilket anses vara en lämplig pedagogik för att visualisera programmeringsprocedurer för barn (Misirli \& Komis, 2014). I Misirli och Komis (2014) studie utvecklade forskarna ett pseudo-språk där man använde sig av en bild på kommando-knappen, en bild på Beeboten där knappen var upplyst samt en text som beskriver kommandot (t.ex. "Sväng vänster"). Språket var representerat på kort som barnen kunde lägga framför sig när de programmerade, vilket enligt forskarna möjliggjorde för barnen att visualisera programmet men också att diskutera och justera det (Misirli \& Komis, 2014).

EnligtMisirli och Komis (2014)saknas ettsystematisktförhållningssätttill hurprogrammeringsbegrepp kan undervisas med hjälp av robotar för yngre elever. Författarna menar att robotarna sällan används i autentiska undervisningssammanhang utan vanligtvis făr eleverna experimentera fritt med robotarna. Att enbart experimentera eller leka med en robot räcker oftast inte för att eleverna ska uppfatta interaktionen med roboten som meningsfull. I Newhouse, Cooper och Cordery (2017) och Jankas (2008) studier tappade eleverna (4-6 år respektive 6 år) snabbt intresset för Beebotarna då det inte fanns något specifikt syfte med att använda dem. Även om eleverna var engagerade var det tveksamt om den fria leken med robotarna stimulerade till handlingar med relevans för programmering (Newhouse, Cooper \& Cordery, 2017). Misirli och Komis (2014) efterfrågar därför innehåll och undervisningssammanhang som motiverar och möjliggör lärande av begrepp utifrån elevernas förutsättningar. Detta ter sig viktigt då det i många fall verkar finnas ett implicit antagande om att elever som får möjlighet att programmera lär sig detta på egen hand utan någon undervisning (Lye \& Koh, 2014).

Sammanfattningsvis har således viss kritik väckts mot skolans programmeringsundervisning och hur den diskuteras av forskningsfältet. Snarare än att undervisa i principer och begrepp fokuseras "verktygshantering” (Haden, Gasson, Wood \& Parsons, 2016). Flera forskare efterfrågar därför ett skifte i fokus: från verktygen till att mer diskutera centrala ämnesdidaktiska frågor som hur användandet av robotarna kan stödja elevers begreppsförståelse (se t.ex. Manches \& Plowman, 2017). Utöver detta saknas även kunskap om hur programmering kan implementeras i skolan generellt (Kjällander, Åkerfeldt \& Petersen, 2016). Detta är också bakgrunden till denna studie vilken har som ambition att bidra till en ökad förståelse för hur programmering kan användas i undervisningen för att stödja elever i att utveckla teknikämnesspecifika förmågor. Studien hörsammar därmed Björkholm, Andrée och Carlgrens (2016) diskussion kring möjliga generativa aspekter av elevers tekniska kunskap som kan utgöra en viktig ämnesdidaktisk kunskapsbas för lärare. Författarna menar att samtidigt som ett ämneskunnande alltid är kopplat till ett specifikt kunskapsobjekt, bör det även finnas aspekter i detta kunnande som är generaliserbart och användbart i andra ämnessammanhang (Björkholm, Andrée \& Carlgren, 2016). Ett exempel på ett sådant kunnande är att värdera tekniska lösningar utifrån funktion och ändamålsenlighet, vilket diskuteras nedan. 


\section{Kod som teknisk lösning}

Centralt i kursplanen för teknikämnet i svensk grundskola är att eleverna ska utveckla kunskaper om tekniska lösningar och arbetssätt för utveckling av tekniska lösningar (Skolverket 2018/2011). Att värdera tekniska lösningar utifrån deras ändamålsenlighet är en central kompetens inom teknisk kunskap (Barlex, 2011). Genom kunskaper om tekniska lösningar utvecklar eleverna sin förmåga att identifiera och analysera tekniska lösningar utifrån dess funktion och ändamålsenlighet vilken är en av fem övergripande förmågorna i kursplanen i teknik. I litteraturen används teknisk lösning synonymt med begrepp som teknisk artefakt, tekniskt objekt eller teknisk konstruktion (Björkholm, 2015) för att beskriva ett mänskligt konstruerat objekt framtaget för att svara mot ett behov. Tekniska lösningar är alltså framtagna för ett specifikt syfte, hur väl lösningen fungerar kan förstås och värderas i relation till dess fysiska och funktionella egenskaper (de Vries, 2005). Ett gångjärn har en materiell dimension där olika komponenter, delar, former och material är valda och designade i relation till ett ändamål. Hur gångjärnet fungerar beror på hur de olika delarna samverkar och en förbättring av deras funktion handlar ofta om att optimera hur de enskilda delarna, med dess specifika egenskaper, samverkar. Oftast tenderar objektets ändamålsenlighet vara det som användaren är intresserad av, d.v.s. hur väl den realiserar sitt syfte snarare än betydelsen av material och konstruktion eller hur den fungerar rent tekniskt (Björkholm, 2014). Att ha kunskap om en teknisk lösnings funktion kan då, enligt Björkholm (2014), handla om förståelse för huruvida objektet uppfyller det den är gjord att uppfylla men också om relationen mellan ändamålsenlighet och objektets konstruktion.

Elever beskriver sällan en teknisk lösnings funktion och grad av ändamålsenlighet som beroende av dess konstruktion, utan tenderar snarare att utgå från personliga preferenser gällande dess kvaliteter (Björkholm, 2014; Compton \& Compton, 2013). Detta är något som Björkholm (2014) undersökt i en studie på yngre elevers (7-8 år) lärande kring tekniska lösningar. I studien arbetar eleverna med förslutningar (skruv- och gångjärnslock) och i detta arbete framkommer fyra olika sätt som elever uppfattar och pratar om tekniska lösningars ändamålsenlighet: (a) effektivitet för mig, (b) effektivitet för andra, (c) konstruktionsberoende samt (d) teknisk effektivitet. Dessa fyra kategorier visar på en möjlig progression i elevers kunnande i att identifiera och analysera tekniska lösningars ändamålsenlighet (Björkholm, 2014). Kategori (a) innefattar elevuppfattningar där ändamålsenlighet är en fråga om hur väl lösningen uppfyller den enskilda elevens specifika behov. Kategori (b) innefattar uppfattningar där ändamålsenlighet inte enbart är funktion för mig, utan även någonting som beror på sammanhang och andra individers behov. De två första kategorierna beskriver således ändamålsenlighet framförallt som hur väl lösningen realiserar det jag, eller andra, vill att den ska göra. De två övriga kategorierna innefattar aspekter som handlar om lösningens konstruktion, d.v.s. hur väl de olika delarna samverkar för att realisera det lösningen är konstruerad att göra. Denna typ av resonemang visar på en mer utvecklad förståelse för tekniska lösningars ändamålsenlighet (Björkholm, 2014).

I relation till kursplanen i teknik och den framskrivna förmågan "att identifiera och analysera tekniska lösningar utifrån ändamålsenlighet och funktion" kan kod förstås som en form av teknisk lösning. Med kod avses här en serie instruktioner skrivna i ett programspråk och tillsammans utgör de delar i ett program. Att skriva kod handlar således om att bestämma hur en serie instruktioner ska utformas. Programmering handlar dock inte bara om att skriva kod, utan även om att hitta på lösningar på problem som alltså realiseras genom koden och programmet. Programmet är framtaget för att verkställa något specifikt och dess funktion, som att styra ett föremål, är beroende av hur programmets olika beståndsdelar samverkar. Att utveckla en förståelse för programmering och kod kan därmed handla om att kunna konstruera och diskutera kod utifrån olika kvaliteter relaterade till dess funktionalitet, som t.ex. enkelhet och effektivitet. Att identifiera och analysera kod blir då en integrerad del i att kunna programmera. I linje med vad Björkholm (2014) visat, kan det alltså vara möjligt att kod kan beskrivas och bedömas i termer av en teknisk lösning som fungerar för mig, fungerar för andra och fungerar som ett resultat av dess konstruktion.

Som litteraturöversikten visar har tidigare forskning framförallt fokuserat lärande kring datavetenskapliga begrepp eller allmänna förmågor och det finns ett behov av att undersöka hur teknikämnets 
nya innehåll kan omsättas i undervisning. Studien syftar därför till att generera kunskap om hur kod och programspråk kan introduceras i grundskolans teknikämne för de yngre åldrarna. Mer specifikt avser studien besvara nedanstående frågeställningar:

- Vad är kännetecknade för elevers spontana programspråk för att styra en enkel robot?

- Vilka uppfattningar om funktion och ändamålsenlighet uttrycker elever när de tillsammans med läraren utvecklar ett gemensamt programspråk för att styra en enkel robot?

\section{METOD}

Studiens data kommer från två grundskolor i Stockholmsområdet. Skola A är en F-9 skola med cirka 600 elever och Skola B är en F-6 skola med cirka 700 elever. Skolorna har liknande upptagningsområde och har båda en homogen elevpopulation. Deltagande elevers vårdnadshavare tog del av och undertecknande en samtyckeshandling där studiens syfte och upplägg presenterades. Studien hade ett undervisningsutvecklande ämnesdidaktiskt fokus och artikelförfattarna designade och genomförde studien tillsammans. Tre av författarna (Björn, Lundholm-Bergström och Wållberg) var undervisade lärare i de klasser som studien genomfördes i, elever och lärare kände således varandra väl. Lektionsaktiviteterna, som syftade till att stödja eleverna i att utveckla en förståelse för programmering och kod, planerades gemensamt av gruppen. Samtliga deltog i databearbetnings - och analysarbetet. Resultatet från analyserna låg till grund för gruppens planering av efterföljande lektionsaktiviteter.

\section{Datainsamling}

Gruppen planerade och genomförde en undervisningssekvens bestående av fem lektionspass som varade mellan 45-6o minuter. Björn, Lundholm-Bergström och Wållberg genomförde lektionspassen med 85 elever i årskurs 1 ( 7 år, skola A) och 27 elever i årskurs 4 (10 år, skola B) och samlade då in datamaterialet. Enbart enstaka elever hade tidigare erfarenheter av att programmera när studien genomfördes. Undervisningssekvensen syftade till att möjliggöra för eleverna att utveckla och enas om ett ändamålsenligt och gemensamt programspråk för att styra enkla robotar. Björn, Lundholm-Bergström och Wållberg utgick från ett pratmanus som gruppen hade tagit fram gemensamt. På grund av tillfälligheter i klassrummet, som frågor eller funderingar från eleverna, valde de ibland att betona vissa aspekter särskilt eller ta in saker i samtalen som vi inte planerat för gemensamt.

Eleverna delades in i grupper om 3 till 4 elever (20 grupper i åk 1 samt 9 grupper i åk 4) och ombads skriva "instruktioner" för att styra en robot så att den utförde en viss rörelse. En annan elevgrupp skulle sedan använda instruktionen för att få sin robot att utföra den förväntade rörelsen. Aktiviteterna utgick således från elevernas erfarenheter och individuella sätt att uttrycka sig, snarare än färdiga definitioner på programmering och kod. I undervisningssekvensens inledningsskede fanns det således inga förgivettaganden gällande programspråkets konstruktion, d.v.s. eleverna kunde använda symboler, bokstäver, etc. Ambitionen var att elevernas instruktioner skulle utgöra en grund för ett gemensamt samtal kring vad som kan känneteckna en bra instruktion. Av denna anledning valde vi att i interventionens inledande skede inte att använda ordet kod utan "instruktion". Begreppet kod introducerades när samtal om ändamålsenlighet initierades. Under undervisningssekvensen kom lärarna och elever att successivt börja använda ordet kod när de pratade om instruktionerna.

Under undervisningssekvensen användes roboten Bluebot. Blueboten programmeras med tryckknappar på ryggen vilka indikerar med pilar en rörelse framåt, bakåt, sväng vänster eller höger (figur 1). Startknappen (GO) är placerad i mitten. Dessutom finns en tryckknapp för paus, markerad med dubbelstreck (ll) och en tryckknapp för att rensa minnet (X). Ett steg framåt renderar en förflyttning med $15 \mathrm{~cm}$. Svänger gör roboten på platsen där den står med 90 grader, då sker ingen förflyttning. Programmering kan göras med ca 80 instruktioner (tryckningar) därefter är 
robotens minneskapacitet full. Trycks kod in utan att radera tidigare kod läggs den nyare koden in efter den tidigare och Blueboten kör hela sekvensen från början.

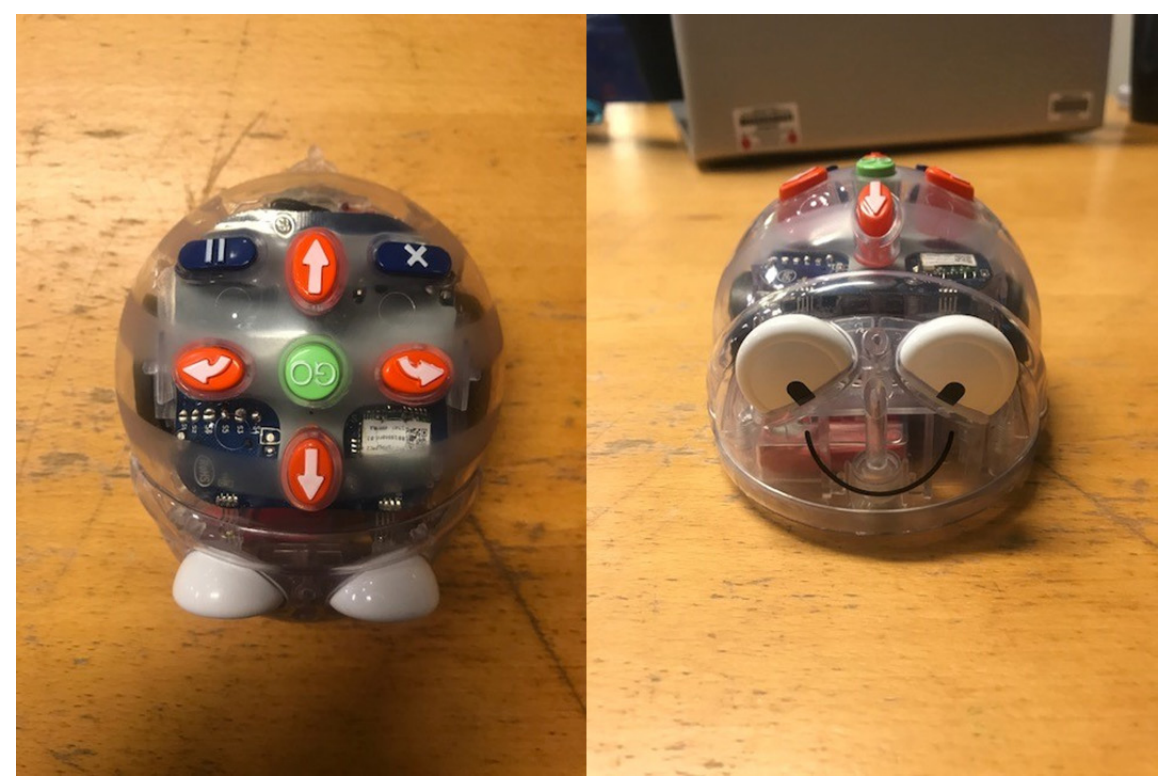

Figur 1. Bluebot

- Moment 1: Introduktion och fri lek med roboten

Läraren berättade om robotar generellt, vad de gör och hur de kan se ut och introducerade sedan Blueboten som eleverna fick testa. Eleverna spelade in det de gjorde via en läsplatta.

- Moment 2: Skriva en instruktion till roboten

Eleverna fick till uppdrag att skriva en instruktion till Blueboten för att den skulle röra sig från A till C via B (beskriva en L-rörelse). Flera elever hade stött på begreppet instruktion och då i relation till svenskämnet (t.ex. skriva recept eller lekregler). Varje elevgrupp fick sedan testa en annan grupps instruktion.

- Moment 3: Skriva en instruktion till roboten

Eleverna fick till uppdrag att skriva en instruktion för att Blueboten med sin rörelse skulle beskriva en bokstav. Varje elevgrupp fick testa en annan grupps instruktion och försöka lista ut vilken bokstav instruktionen skulle beskriva.

- Moment 4: Vad kännetecknar en bra instruktion?

I helklass jämförde och diskuterade eleverna och läraren olika elevexempel på kod utifrån vad som kan känneteckna bra kod.

- Moment 5: Skriva en instruktion till roboten

Utifrån samtalen i moment 4 konstruerades en mer komplex uppgift där roboten skulle göra en längre och mer varierad rörelse. Eleverna fick i uppdrag att programmera specifika ord (Regn, Aldrig, Poäng, Sjö) där roboten genom sin rörelse skulle beskriva de olika bokstäverna. Elevernas instruktioner diskuterades sedan i helklass.

Elevernas och lärarens samtal spelades in med diktafoner och läsplattor under samtliga lektioner. Under moment 1-3 använde eleverna i Skola B läsplattor för att filma sitt arbete. I skola A användes diktafoner och filmkamera. Samtliga instruktioner från lektion 2-3 samlades in och utgjorde underlaget för helklassdiskussionen moment 4. En övergripande kartläggning gjordes av ljud - och bildmaterialet i syfte att hitta material med relevans för studiens forskningsfrågor. Intressanta sekvenser transkriberades och analyserades. 


\section{Dataanalys}

Dataunderlaget består av två delar, dels de instruktioner eleverna skrev under moment 2-3 och dels transkriberade ljudupptagningar från samtliga moment. Analysen av elevernas instruktioner syftade till att synliggöra vad som är kännetecknande för elevers spontana programspråk och därmed besvara forskningsfråga 1. En enkel kategorigenererande innehållsanalys genomfördes (Hsieh \& Shannon, 2005) där vi inledningsvis fokuserade på instruktionernas modalitet. Instruktionerna sorterades i högar som fick utgöra preliminära kategorier, kategorierna justerades successivt beroende instruktionernas innehåll. Detta steg genererade tre övergripande kategorier, bild, text och symbol, till vilka elevernas instruktioner sorterades. Varje kategori analyserades vidare och i denna process framkom underkategorier (t.ex. en kombination av symbol och siffra) samt skillnader i instruktionernas läsriktning. Oklara instruktioner lades åt sidan och diskuterades. När samstämmighet rådde mellan författarna placerades instruktionen i någon av de framkomna kategorierna. Samtliga instruktioner (44 st), kunde sorteras i enlighet med de övergripande kategorier som genererats ur materialet.

Det andra steget i analysen av klassrumssamtalen syftade till att synliggöra hur eleverna resonerade kring deras spontana programspråk i termer av funktion och ändamålsenlighet. I detta steg fokuserades således forskningsfråga 2. Elevernas uppfattningar och förståelse för undervisningens innehåll analyserades med hjälp av organiserande syften (Johansson \& Wickman, 2011). Organiserande syften utgår från två analytiska begrepp: närliggande och övergripande syften (Johansson \& Wickman, 2011). Undervisningens övergripande syfte beskriver det lärande som läraren avser att undervisningen ska leda fram till. Eftersom detta kunskapsinnehåll, d.v.s. det lärande som ska ske på lektionen, vanligtvis är nytt för eleverna behöver läraren organisera för aktiviteter, innehåll, samtal, instruktioner, etc. som eleverna kan relatera till och förstår. Dessa är undervisningens närliggande syften. Om det närliggande syftet är begripligt för eleven och hen kan agera i relation till det, säger man att det utgör mål-i-sikte (Johansson \& Wickman, 2011). Analysen fokuserade särskilt på tillfällen i samtalen där kvalitativa aspekter på instruktionerna berördes. Intressanta partier diskuterades och sorterades i enlighet med Björkholms (2014) kategorier (1) effektivitet för mig, (2) effektivitet för andra, (3) konstruktionsberoende samt (4) teknisk effektivitet. Snarare än att kvantifiera utsagor, syftade tematiseringen till att extrahera och synliggöra eventuella variationer i hur ändamålsenlighet konstitueras när elever skriver instruktioner. Utfallet av analysen användes för att planera efterföljande lektionsmoment.

\section{RESULTAT}

Undervisningssekvensen hade som mål att stödja eleverna i att utveckla och enas om ett gemensamt programspråk för att styra ett föremål. Undervisningens övergripande syfte var att möjliggöra för eleverna att förstå och prata om kod i termer av funktion och ändamålsenlighet. De närliggande syftena, som också blev mål-i-sikte för eleverna, var att: testa att styra en robot (moment 1), skriva en instruktion som beskriver en L-rörelse (moment 2-3), använda en annan grupps instruktion (moment 2-3), i helklass samtala om vad som kan vara ett gemensamt programspråk (moment 4 och 5). Nedan presenteras resultatet i relation till studiens två forskningsfrågor, avsnittet avslutas med en sammanfattning.

\section{Vad är kännetecknade för elevers spontana programspråk för att styra en enkel robot?}

I momenten 2 och 3 ombads eleverna skriva instruktioner och sedan använda en annan elevgrupps instruktioner till att styra en robot. Eleverna fick inga anvisningar om hur en sådan skulle se ut utan det var fritt för varje elevgrupp att välja hur man ville göra detta. För de flesta av de äldre eleverna var detta en relativt enkel uppgift, endast i undantagsfall pratade eleverna om hur instruktionen skulle se ut (t.ex. använda text eller symboler). Att skriva en instruktion blev således mål-i-sikte för eleverna.

Elevernas instruktioner kunde sorteras in i tre övergripande kategorier: (1) Bild, (2) Ord och (3) Symboler (som pilar och likhetstecken). Inom kategori Ord och Symboler fanns underkategorier och för alla kategorier kunde olika läsriktningar; horisontell, vertikal och spatial orientering, urskiljas. Hor- 


\section{Anderhag et al.}

isontell avser en läsning från vänster till höger, vertikal en läsning uppifrån och ner med ny rad vid varje nytt kommando och spatial avbildar, genomgående med pilar och/eller streck, robotens faktiska rörelse i rummet. Se figur 2-7 samt tabell 1, Kategori (1) innehåller de instruktioner som endast med bild visat robotens väg, Kategori (2) innefattar de elevinstruktioner vilka innehåller skriven instruktion, och kategori (3) de elevinstruktioner vilka innehåller symboler som pilar och likhetstecken.

Tabell 1 Kategorisering av elevgruppers (åk1 och åk4) spontana programspråk

\begin{tabular}{|c|c|c|c|c|c|c|c|c|c|c|c|c|}
\hline \multirow[t]{3}{*}{ Orientering } & \multicolumn{2}{|c|}{ Bildbaserad } & \multirow{2}{*}{\multicolumn{2}{|c|}{$\frac{\text { Ordbaserad }}{\text { Ord+siffra }}$}} & \multicolumn{8}{|c|}{ Symbolbaserad } \\
\hline & \multirow[b]{2}{*}{ åk 1} & \multirow[b]{2}{*}{ åk 4} & & & \multicolumn{2}{|c|}{ Symbol } & \multicolumn{2}{|c|}{$\begin{array}{l}\text { Symbol + } \\
\text { ord }\end{array}$} & \multicolumn{2}{|c|}{$\begin{array}{l}\text { Symbol + } \\
\text { siffra }\end{array}$} & \multicolumn{2}{|c|}{$\begin{array}{l}\text { Symbol + } \\
\text { ord + siffra }\end{array}$} \\
\hline & & & åk 1 & åk 4 & åk 1 & åk 4 & åk 1 & åk 4 & åk 1 & åk 4 & åk 1 & åk 4 \\
\hline Spatial & 2 & - & - & - & 10 & - & 3 & - & 4 & 1 & 8 & - \\
\hline Horisontell & - & - & 8 & 1 & - & - & - & - & - & 1 & - & 1 \\
\hline Vertikal & - & - & 2 & 2 & - & - & - & - & - & 1 & - & - \\
\hline
\end{tabular}

Orientering beskriver skriv- respektive ritriktning. Siffrorna anger antal instruktioner inom varje kategori, totalt 44 stycken.

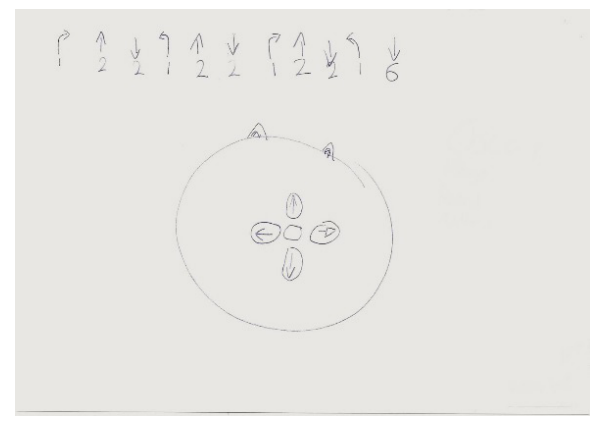

Figur 2. Symbolbaserat (symbol + siffra) horisontellt orienterat programspråk (åk4)

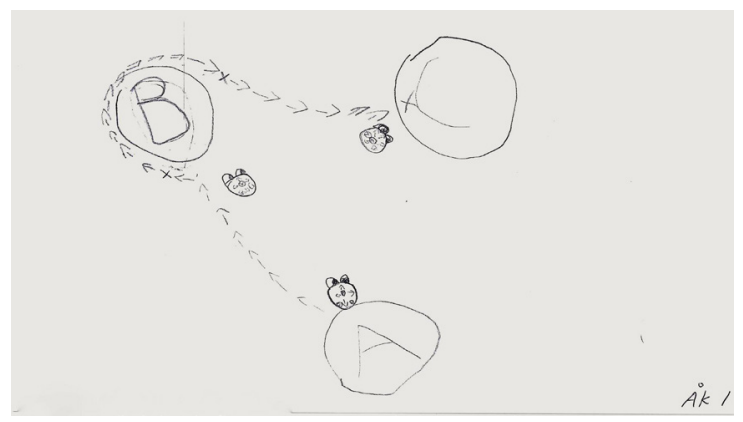

Figur 3. Symbolbaserat spatialt programspråk (åk1)

$$
\begin{aligned}
& y=1 \\
& y=k \\
& z=1
\end{aligned}
$$

Figur 4. Symbolbaserat (symbol + siffra) vertikalt orienterat programspråk (åk1)

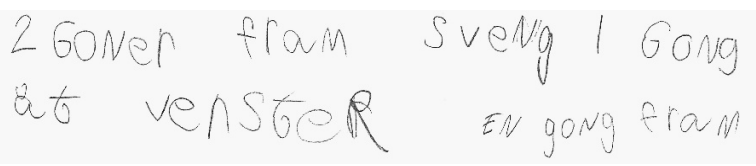

Figur 5. Ordbaserat (ord+siffra) horisontellt orienterat programspråk (åk1) 


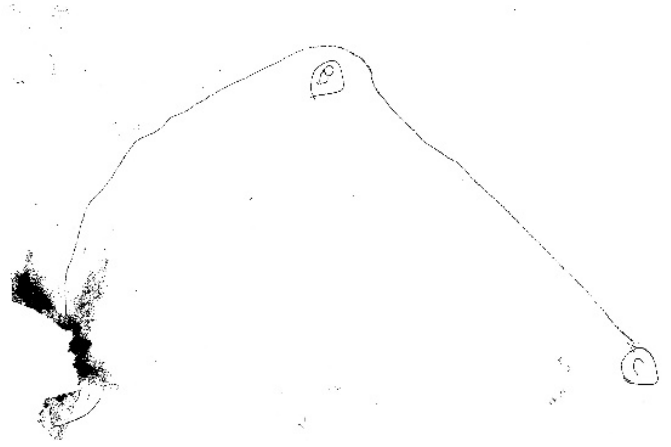

Figur 6. Bildbaserat programspråk (åk1)

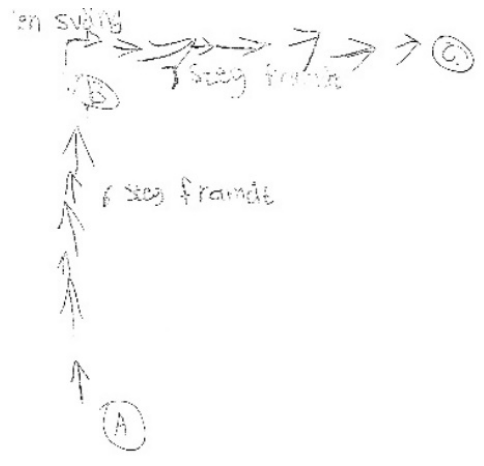

Figur 7. Symbolbaserat (symbol+ord+ siffra) spatialt programspråk (åk1)

Endast i undantagsfall diskuterade eleverna instruktionens modalitet och läsriktning och nedanstående två samtal exemplifierar hur samtalen mellan eleverna oftast såg ut när de skrev sina instruktioner. Exempel 1 visar ett tillfälle då "skriva en instruktion" inte var mål-i-sikte för en av eleverna, vilket dock var ovanligt i materialet. I den här gruppen (åk 4) valde eleverna att använda siffror och symboler i form av pilar i sin instruktion (se även figur 8):

\section{Exempel 1: Kod som siffror och symboler}

1. Elev 1: Åtta, skriv åtta. Och en pil framåt.

2. Elev 2: Framåt?

3. Elev 1: Uppåt. Så. [Visar med pekfingret på pappret]

4. Elev 2: Såhär? [Ritar en framåt-pil]

5. Elev 1: Precis.

6. Elev 1: sen vänster. Ett.

[Elev 2 vet inte hur hen ska skriva och lämnar över pappret till Elev 1] [...]

7. Elev 1: Sen var det åtta igen. Sådär.

8. Elev 2: Men då, men vi skulle ju skriva instruktion? Skriva instruktioner?

9. Elev 3: Men vi har ju gjort det nu.

10.Elev 2: Har vi gjort det? Är det här instruktionerna?

Även om elev 2 inledningsvis är osäker på hur hen ska skriva, är eleverna överens om instruktionens modalitet (siffror och pilar) och funktionella användning. Framåt-pil och 8 ska representera och realisera en specifik rörelse i instruktionen (rad 1-3). Elev 2 är också osäker på vad det är de håller på med har att göra med den instruktion de ska skriva. En osäkerhet uppmärksammades således i samtalet, vi skulle ju skriva instruktion ( $\operatorname{rad} 8)$ som sedan besvarades i rad 10, Âr det här instruktionerna?

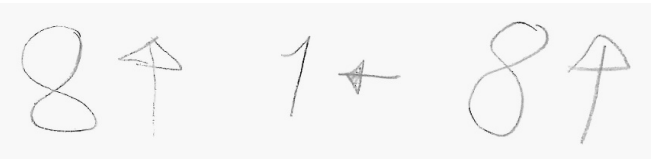

Figur 8. Elever i årskurs 4 använder symboler och siffror för att skriva sin instruktion

I exempel 2 och tillhörande figur 9, som kommer från årskurs 1, använde eleverna bokstäver och skrev korta meningar i sin instruktion. 


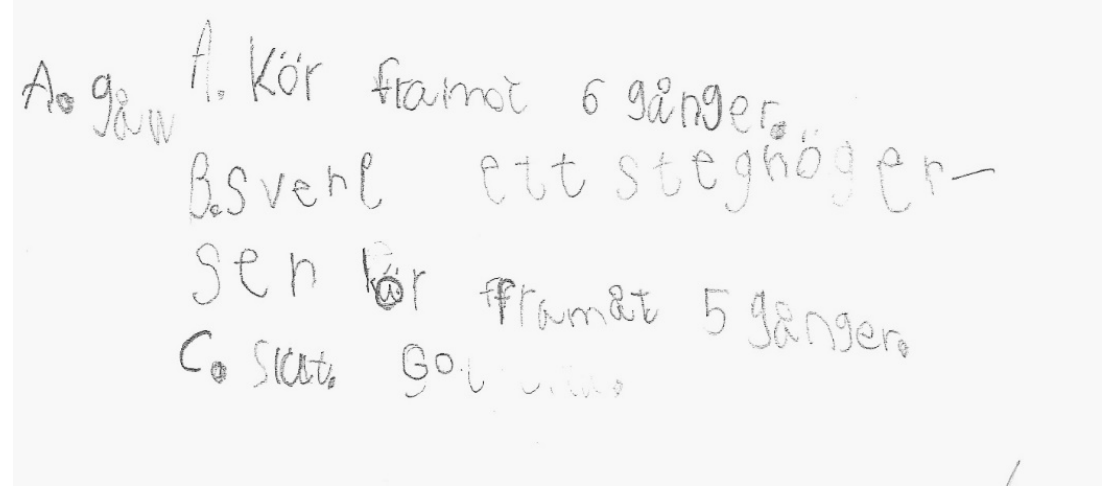

Figur 9. Elever $i$ årskurs 1 använder naturligt språk för att skriva sin instruktion

I likhet med vad som nämnts ovan var modaliteten inget som eleverna pratade om innan de började skriva sin instruktion, för dem var således ord och meningar ett meningsfullt sätt att instruera roboten.

\section{Exempel 2: Kod som naturligt språk}
11. Elev 1: Då skriver vi fram sex gånger.
12. Elev 5: Fram sex gånger.
13. Elev 1: Ja precis. Vi skriver vid A, skriv vid A
14. Elev 1: [Ljudar ihop meningen]
15. Elev 1: Kör framåt sex
16. Elev 2: Min tur att skriva
17. Elev 2: Vid B
18. Elev 1: Sväng, sväng
19. Elev 2: Nej, kör sväng ja
20. Elev 1: Okej vi provar med e
21. Elev 1: Är det med n-g?
22. Elev 2: $\mathrm{N}-\mathrm{g}$
23. Elev 1: Sväng sex

Eleverna i årskurs 1 ägnade mycket tid till att stava orden och prata om vem som skulle göra vad, vilket ovanstående excerpt exemplifierar.

\section{Vilka uppfattningar om funktion och ändamålsenlighet uttrycker elever när de till- sammans med läraren utvecklar ett gemensamt programspråk för att styra en enkel robot?}

\section{Ändamålsenlighet som läsbarhet för mig och andra}

Under elevernas arbete med att skriva och sedan använda en annan grupps instruktioner uppmärksammades ibland kvaliteter i koden. Vanligtvis handlade det om funktionalitet i termer av att skriva och läsa koden och oftast då i relation till den specifika elevgruppens behov. Eleverna uttryckte sällan ett behov att förändra eller tydliggöra koden som inledningsvis, beroende på uppgiftens konstruktion (moment 2 och 3), resulterade i en rad symboler eller ett par rader skriven text. I slutet av interventionen introducerades därför en uppgift där eleverna behövde skriva en längre och mer varierad instruktion (moment 5). 
Som beskrivits ovan ägnade eleverna i årskurs 1 mycket tid till att stava orden och prata om vem som skulle göra vad. För de yngre eleverna handlade således att skriva en instruktion framför allt om att ord och meningar blev korrekta. Hur väl en kod fungerar var också en fråga om sammanhang. Om det handlade om att läsa koden kunde eleverna värdera spatiala (figur 3), snarare än vertikala eller horisontella, kodsekvenser som ändamålsenliga. Detta då robotens förväntade rörelse i rummet var lätt att uttyda i dessa. Om det handlade om att skriva en mer komplex kod, vilket i studiens sammanhang handlade om att skriva en längre och mer varierad kod, kunde eleverna föredra andra mer konventionella instruktioner. Vad som kännetecknar en kods ändamålsenlighet för eleverna var således beroende på om det handlade om att skriva eller att läsa koden.

I samtal med läraren kom diskussionen även in på ändamålsenlighet för andra, d.v.s., är den här koden funktionell för någon annan än mig? Ofta handlade det om att göra koden tydligare för andra att läsa, om koden var i form av naturligt språk uppmärksammade läraren eleverna på tillfällen där läsaren kanske inte kan svenska. I exempel 3 (åk 4) använde eleverna streck i sin instruktion för att representera rörelse framåt. När läraren kom in i samtalet satt eleverna och räknade högt och pekade på strecken de hade ritat. I samband med detta frågade läraren eleverna om koden kan göras tydligare:

\section{Exempel 3: att använda pilar istället för streck}

24. Lärare: Hm, men du det där är väldigt lätt att se fel på, kunde ni ha gjort det lite tydligare på något sätt?

25. Elev 6: Äh, jag vet [Går och hämtar en penna]

26. Lärare: Hur kunde ni ha gjort då?

27. Lärare: Hur ser det ut på den här [Visar fram Bluebotens knappar]

28. Elev 4: Det är pilar.

29. Lärare: Pilar, Ja, kunde man använt dom kanske?

30. Elev 4: [skratt] Ja pilar!

31. Lärare: Ja, men fixa det då. [sägs uppmuntrande]

32. Elev 6: Tusen pilar

33. Lärare: Använd de här strecken [pekar på de streck eleverna skrivit] det är bara att sätta pilar på.

Läraren uppmärksammade eleverna på att strecken kan vara svåra att uttyda och bad dem fundera på alternativa, "lite tydligare”, sätt att skriva kod på ( $\operatorname{rad} 24)$. Läraren visar knapparna på Blueboten (rad 27) och tillsammans med eleverna enades man om att pilar, även om det blir "tusen” pilar ( $\operatorname{rad} 32)$, kunde vara ett mer tydligt sätt att skriva på.

I nästa exempel, som kommer från en helklassdiskussion i årskurs 4, pratar läraren och eleverna om två olika former av symbol-kod som läraren skrivit och visat eleverna (se figur 10). De två formerna baseras på elevernas egna spontana programspråk, den ena består av enbart av pilar och den andra av siffror och pilar.

\section{Exempel 4: att använda symboler och pilar}

34. Läraren: Pilar och siffror? Vad är det för skillnad på fyran och femman [två olika exempel på kod] då?

35. Elev 7: Den här femman, den har siffror, och pilar, fyran, den har bara, så många pilar som det är.

36. Läraren: Ja?

37. Elev 8: Det blir såhär, jättemycket pilar, man vet liksom inte riktigt, då måste man sitta och räkna en två tre fyr fem sex sju, åtta också en två tre fyr, höger, en två alla pilarna, det blir jättejobbigt. Men dom kanske inte har det som höger? Eller jo, det har dom nog.

38. Läraren: Det är jobbigt att räkna, det blir lättare med en siffra?

39. Elev 7: Ja, det blir lättare då. Det sitter liksom åt ett håll. 
4

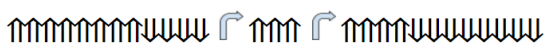

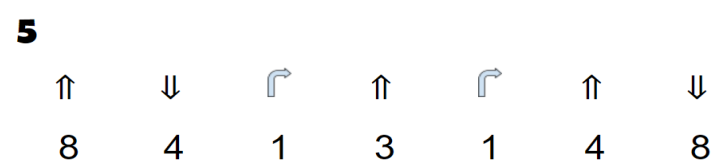

Figur 10. Två varianter av symbolbaserat programspråk som baseras på de instruktioner eleverna skrev till robotarna

I likhet med de exempel som presenterats ovan var läsbarhet den kvalitetsaspekt som eleverna och läraren diskuterade och då i relation hur koden kan göras tydligare. Siffror var vid detta tillfälle något som eleverna och läraren såg som ett möjligt förtydligande inslag i koden. Det var ovanligt att diskussioner kring läsbarhet kom upp spontant i elevernas egna samtal utan detta skedde framförallt när läraren uppmanade eleverna att reflektera över detta. Majoriteten av eleverna, oavsett årskurs, uttryckte sällan att de såg några fördelar med ett mer abstrakt, symbolbaserat, programspråk. Eleverna uppfattade ord och meningar som funktionella i detta sammanhang. När eleverna ombads fundera kring vilka sammanhang symboler och siffror kan vara användbara, föreslog eleverna tillfällen när läsaren inte förstår svenska eller när man behöver skriva mycket text och därmed kan effektivisera detta genom att använda symboler istället.

\section{Ändamålsenlighet som att koden gör det den ska}

Som beskrivits ovan fokuserade de lärarstyrda samtalen framförallt på att uppmärksamma eleverna på kodens läsbarhet och eventuella förbättringar som kunde göras i relation till detta. I materialet var det därför ovanligt att eleverna talade om kodens konstruktion i relation till vad den förväntas göra, d.v.s. hur dess olika delar samverkar för att realisera det den är framtagen att utföra (styra en robot på ett specifikt sätt). Ibland berörde dock samtalen också kvaliteter i termer av att koden gör det den ska på ett ändamålsenligt sätt, vilket nedanstående exempel visar. Eleverna har efter uppmaning av läraren ritat pilspetsar på de streck de tidigare skrivit och nu är det dags att testa koden:

\section{Exempel 5: justering av kodens konstruktion}

40. Lärare: Ska vi pröva? Tror ni det fungerar. Vi prövar. Men var det någon som stängde av den? 41. Elev 4: Det gjorde ju du!

42. Lärare: Vi sätter den på A [sätter på den igen]

43. Lärare: Den ska gå [pekar och visar den riktning roboten ska röra sig]

44. Lärare: Ett, två, tre, fyra, fem, sex, sju, åtta, nio, tio, elva, tolv. [trycker med fingret på Bluebot samtidigt pekar på koden på pappret]

45. Elev 6: Det ska vara en sväng emellan.

46. Lärare: Det har ni inte skrivit [de trycker på "Go”]. Nej men, nu svängde den. Det där vart jättekonstigt.

47. Elev 4: Men där svänger den [drar med fingret längs pappret].

48. Lärare: Jag provar igen. Vi prövar igen. [trycker in koden igen]

49. Lärare: Ett, två, tre, fyra, fem, sex. Ett, två, tre, fyra, fem, sex [trycker med fingret på Blueboten och pekar samtidigt på koden på pappret].

50. Elev 6: Det ska vara en sväng emellan.

51. Lärare: Ja, men den har ni inte skrivit. 
När eleverna testade koden visade det sig att roboten inte rörde sig som planerat. Detta berodde på att eleverna glömt att sätta ut en "Sväng" i koden, vilket en elev uppmärksammade läraren på ( $\operatorname{rad} 45$, 50) och en annan använde den nedtecknade koden för att visa var en svängande rörelse skulle ske (rad 47). I det fortsatta samtalet fanns ett ytterligare tillfälle då roboten uppförde sig oväntat och tillsammans med läraren upptäckte eleverna en ytterligare plats i programmet där de glömt att sätta ut en anvisning för "Sväng". Exemplet visar således på ett tillfälle då ett programs funktion diskuteras och justeras på grund av brister i dess konstruktion, eleverna och läraren upptäcker att det saknas kod.

Enbart i undantagsfall pratade eleverna om alternativa, mer effektiva och bättre kodsegment, för att få roboten att röra sig. Nedanstående excerpt exemplifierar ett sådant undantagsfall. I exemplet pratade läraren och eleverna om "Kryssets" funktion i den kod eleverna skrivit och i samband med detta diskuterar läraren och en elev kodens betydelse för att få roboten att göra det den förväntas.

\section{Exempel 6: roboten beter sig konstigt}

52. Lärare: Hur går det för er här? Hur har ni tänkt? Berätta för mig. Berätta hur har ni ritat där då?

53. Elev 9: Först framåt, och då vi har satt pil [Visar på teckningen av Blueboten]. Man ska sex framåt. Det är det första.

54. Lärare: Men vad är kryssen?

55. Elev 9: Det är radera.

56. Lärare: Varför ska jag radera?

57. Elev 9: Bara för att den inte ska göra samma sak.

58. Lärare: För att den inte ska göra samma sak? Berätta för mig. Jag bara undrar hur har ni tänkt med radera?

59. Elev 9: Man måste radera mellan för att inte Blueboten ska bli så konstig.

6o. Lärare: Blir den konstig om den får för mycket information?

61. Elev 9: Ja

62. Lärare: Jaha okej. Vad händer sedan då. Ett steg radera, ett steg radera, ett steg radera, ett steg radera, ett steg radera, ett steg radera.

63. Elev 9: Sex gånger på den knappen [Pekar på ritningen av Bluebot]. Sedan är det sväng en gång [Pekar på ritningen och på högerpil]. Det är där [Visar var i koden han befinner sig]

64. Lärare: Aa!

65. Elev 9: Sedan är det fjorton rakt fram.

66. Lärare: Okej. Då förstår jag.

I denna grupp styrde man roboten genom att trycka in koden successivt och stegvis efter varje rörelse. Gruppen upptäckte då att all kod som tryckts in utfördes av roboten när man tryckte på "Go“, vilket innebar att den repeterade tidigare rörelse vilket i sin tur gjorde att den hamnade fel. Även om man kan argumentera för att detta inte var en effektiv kod (som behöver matas in successivt) är poängen här att eleverna fört in ett segment som åtgärdar det faktum att roboten beter sig konstigt (rad 59). I denna grupp var således "Kryssen" ett nödvändigt element i koden för att roboten inte skulle göra samma sak och inte bete sig konstigt.

\section{Resultatsammanfattning}

Analysen visade på en stor variation i elevernas spontana programspråk men kan ändå kategoriseras $\mathrm{i}$ tre övergripande kategorier: bild, text och symboler. Inom varje kategori fanns det en variation i kodens läsriktning: spatial, horisontell och vertikal. Förmågan att identifiera och analysera tekniska lösningar utifrån ändamålsenlighet och funktion fick olika innebörd i samtalen beroende på om det handlade om att: läsa kod, skriva kod eller trycka in koden. Förståelse för kodens funktion och ändamålsenlighet, som var undervisningens övergripande syfte, var i samtalen framförallt en fråga om läsbarhet för mig och andra. I undantagsfall var ändamålsenlighet en fråga om att koden gör det den ska. Behov av att tydliggöra eller förbättra koden framkom framförallt när eleverna skrev längre och mer varierade instruktioner. 


\section{DISKUSSION}

I denna studie planerades, genomfördes och analyserades ett antal undervisningsmoment i syfte att undersöka hur programspråk och kod kan introduceras i grundskolans teknikämne för de yngre åldrarna. Studien har fokuserat på elevers spontana programspråk samt vilka uppfattningar som elever i årskurs 1 och 4 uttrycker kring kodens ändamålsenlighet. Studien förhåller sig till Skolverkets (2018) skrivelser om att teknikämnet ska ge eleverna förutsättningar att utveckla sin förmåga att identifiera och analysera tekniska lösningar utifrån dess ändamålsenlighet och funktion. Kod förstås i studien som en form av teknisk lösning och i likhet med andra tekniska lösningar kan ändamålsenlighet vara en fråga om hur väl lösningen realiserar det den är framtagen att göra. Undervisningsmomenten hade som ambition att eleverna med stöd från läraren skulle utveckla ett gemensamt och ändamålsenligt programspråk för att styra en enkel robot.

Aktiviteterna fungerade som mål-i-sikte för eleverna och de hade inga svårigheter med att skriva instruktioner för att styra en enkel robot. Endast i undantagsfall pratade eleverna om vilken modalitet som skulle användas när de skrev eller ritade sina instruktioner. Inte heller instruktionens läsriktning eller orientering diskuterades av eleverna under arbetet. Det konventionella sättet att skriva kod vertikalt, som bland annat kännetecknar programspråket LOGO som ligger till grund för Bluebotens programspråk (Misirli \& Komis, 2014), användes sparsamt av eleverna. Oavsett vilken typ av spontant programspråk som eleverna använde var instruktionerna ett stöd när de programmerade robotarna. I likhet med det pseudo-språk i form av lappar med symboler som Misirli och Komis (2014) introducerade i sin studie var elevernas spontana programspråk således funktionella för att prata om relationen mellan kod och robotens rörelse.

Studien visar också att värderande uppfattningar om programspråket var tydligt sammanflätade med sammanhanget. Om det handlade om att bedöma ett program som styr ett föremåls rörelse i rummet uppfattades spatiala koder med bilder och symboler som mest ändamålsenliga. Om det däremot handlade om att skriva kod kunde eleverna föredra ett naturligt språk. Studien visar således på en variation i elevers spontana programspråk och vi kan bara spekulera men det är rimligt att anta att de kategorier som presenterats, d.v.s. läsbarhet och att koden gör det den ska, kan vara användbara för att tala om elevers spontana programspråk. Även om fler studier behövs för att utreda hur representativa kategorierna är kan resultatet användas för att prata om vad som eventuellt kan vara en progression i kunnandet att skriva kod. Givet sammanhangets betydelse kan denna progression beskriva en rörelse från ett naturligt språk till ett mer abstrakt symbolbaserat. Det är rimligt att anta att en undervisning som syftar till att stödja en sådan progression behöver möjliggöra för eleverna att erfara när naturligt språk och/eller spatialt språk inte är funktionellt. Ett sådant sammanhang kan vara då eleverna behöver skriva ett mer komplext program.

Resultatet väcker frågor kring hur programmering kan introduceras i teknikämnet. I likhet med vad flertalet studier visat kan även denna studie argumentera för att enkla robotar uppskattas och kan verka motiverande för eleverna (Highfield, 2010; Newhouse, Cooper \& Cordery, 2017). Samtliga elevgrupper uttryckte sig positivt och arbetade engagerat. Det är också rimligt att anta att eleverna även tränade sin samarbets- (se t.ex. Bers \& Horn, 2010), och problemlösningsförmåga (Green, Wagner \& Green, 2018; Misirli \& Komis, 2014). Alla elevgrupper var noga med att fördela arbetet och hjälpa varandra när de skrev de olika kommandona. Även om studien kan visa på positiva konsekvenser av att använda enkla robotar är det oklart vilken betydelse den typen av processer kan ha för elevernas lärande i teknikämnet eller programmering specifikt. Studier som undersöker generiska förmågors relation till ett ämnesinnehåll kan således behövas. Samtidigt, och i linje med vad flera författare har diskuterat (Klasander, 2010, Hallström, 2018), är det viktigt att betona behovet av forskning kring hur undervisning kan stödja elever i att utveckla ett teknikämnesspecifikt kunnande.

I likhet med Beraza, Pina och Demo (2010) kan studien visa på problematiska begränsningar när enkla robotar ska användas för att introducera programmering. En sådan utmaning handlar om det faktum att koden som skrivs ned måste tryckas in på den fysiska robotens knappar. För vissa elever framstår kodskrivandet som ett onödigt steg när de kan trycka in koden direkt. Detta kan avhjälpas 
med att aktivt introducera felsökning som ett centralt steg i programmeringsprocessen. Behovet av att felsöka kräver dock en viss grad av komplexitet i den uppgift roboten ska genomföra. Då Blueboten inte har några sensorer kan den inte ändra sin rörelse efter den har programmerats. Möjligheterna till att programmera Blueboten är således begränsade (Beraza, Pina och Demo, 2010; Kazakoff, Sullivan \& Bers, 2013) och ett mer avancerat program innebär i princip enbart en längre kod. Detta behöver dock inte betyda att uppgiften blir mer komplex eller mer meningsfull. En didaktisk utmaning handlar således om att designa uppgifter där programmering av en enkel robot blir meningsfullt i relation till teknikämnets kunskapsinnehåll, snarare än ett oreflekterat görande där intresseobjektet är föremålet som styrs (Haden, Gasson, Wood \& Parsons, 2016).

Studien utgör ett bidrag till Björkholm, Andrée och Carlgrens (2016) diskussion kring hur ett specifikt teknisk kunnande, att värdera tekniska lösningars ändamålsenlighet, kan konkretiseras och överföras mellan olika ämnesinnehåll. Kvalitativa skillnader i hur elever uppfattar tekniska lösningars ändamålsenlighet kan även vara en användbar kategorisering för att precisera vad ett kunnande i programmering kan vara. I linje med Björkholm, André och Carlgren (2016) handlade det inledningsvis om att kunna precisera aspekter som gör att den tekniska lösningen är funktionell för mig och andra. I denna studie framstod funktion framförallt som en fråga om tydlighet i läs- och skrivbarhet och det var dessa aspekter som gjorde koden ändamålsenlig. Ett mer avancerat kunnande behandlar relationen mellan den tekniska lösningens konstruktion och funktion (Björkholm, 2014). I denna studie innebar detta huruvida koden realiserar det den är konstruerad att utföra. I likhet med andra studier som undersökt elevers uppfattningar om tekniska lösningars ändamålsenlighet (Björkholm, 2014; Compton \& Compton, 2013) värderade eleverna spontant koden utifrån hur den uppfyller deras personliga behov. Vad som var kännetecknande för kodens ändamålsenlighet utmärktes i interventionens inledningsfas av elevernas personliga preferenser kring dess läsbarhet. Under interventionen kom elevernas uppfattningar att förändras mot det Björkholm (2014) benämner som effektivitet för andra, d.v.s. att en teknisk lösnings ändamålsenlighet kan värderas utifrån hur väl den uppfyller andra personers behov. Detta skedde som ett resultat av att lärarna aktivt uppmärksammade eleverna på sammanhang där t.ex. ett naturligt språk eller ett stort antal streck var mindre funktionellt. Endast i undantagsfall framkom uppfattningar som kan beskrivas som den mer utvecklade förståelsen, konstruktionsberoende, det som vi i studien benämnt som att koden gör det den ska. Det vill säga eleverna värderade inte kodens konstruktion i relation till dess funktion, att styra ett föremål. Det är möjligt att programmet var för enkelt och att det därför inte fanns någon möjlighet eller anledning att prata om hur väl kodens enskilda delar samverkar för realisera det programmet är framtaget att göra. Huruvida programmets komplexitet öppnar upp för mer funktionsberoende resonemang kring kodens ändamålsenlighet är dock en empirisk fråga som behöver undersökas.

Slutligen, studien har genomförts i tre klassrumsammanhang och levererar således inga slutgiltiga svar. Fler studier behövs och ett intressant upplägg vore att undersöka årskurser och sammanhang där andra programmeringsmiljöer används. Resultatet från denna studie kan dock vara en utgångspunkt för att resonera och reflektera kring och därmed utgöra ett stöd för de didaktiska beslut som ständigt görs i klassrummet.

\section{REFERENSER}

Balanskat, A., \& Engelhardt, K. (2015). Computing our future: Computer programming and coding. Priorities, school curricula and initiatives across Europe. Bryssel, Belgien: European Schoolnet.

Barlex, D. (2011). Dear minister, this is why design and technology is a very important subject in the school curriculum. Design and Technology Education: An International Journal, 16(3), 9-18.

Beraza, I., Pina, A. \& Demo, B. (2010). Soft \& Hard ideas to improve interaction with robots for Kids \& Teachers. I Workshop proceedings of SIMPAR 2010 Intl. Conference on simulation, modelling and programming for autonomous robots, 549-557. 
Bers, M.U. \& Horn, M.S. (2010). Tangible programming in early childhood. I I.R. Berson, M.J. Berson (red.) High-tech tots: Childhood in a digital world, Information Age Publishing, Greenwich, CT, 49-70.

Bers, M.U., Flannery, L., Kazakoff, E.R., \& Sullivan, A. (2014). Computational thinking and tinkering; Exploration of an early childhood robotics curriculum. Computers \& Education, 72, 145157. doi:10.1016/j.compedu.2013.10.020

Björkholm, E. (2014). Exploring the capability of evaluating technical solutions: a collaborative study into the primary technology classroom. International Journal of Technology and Design Education, 24(1), 1-18. doi:10.1007/s10798-013-9240-1

Björkholm, E. (2015). Konstruktioner som fungerar: en studie av teknikkunnande i de tidiga skolåren. Diss. Stockholm: Stockholms universitet.

Björkholm, E., Andrée, M. \& Carlgren, I. (2016). Exploring technical knowledge in the primary technology classroom. Australian Journal of Technology Education, 3, 2-16. doi:10.15663/ajte. v3i1.23

Clear, T. (2015). Everybody must cut code! Educational imperative, fad or fantasy? ACM

Inroads, 6(4), 19-21. doi:10.1145/2822902

Compton, V. J., \& Compton, A. D. (2013). Teaching the nature of technology: Determining and supporting student learning of the philosophy of technology. International Journal of Technology and Design Education, 23(2), 229-256. doi:10.1007/s10798-011-9176-2

De Michele, M.S., Demo, G.B., \& Siega, S. (2008). A piedmont schoolnet for a k-12 mini-robots programming project: Experiences in primary schools. I Proceedings of the TERECoP Workshop "Teaching with robotics, Conference SIMPAR. doi:10.1.1.146.2606

de Vries, M.J. (2005). Teaching about technology: An introduction to the philosophy of technology for non-philosophers. Dordrecht: Springer. doi:10.1007/1-4020-3410-5

Green, T., Wagner, R., \& Green, J. (2018). A Look at Robots and Programmable Devices for the K-12 Classroom. TechTrends, 1-9. doi:10.1007/s11528-018-0297

Haden, P., Gasson, J., Wood, K., \& Parsons, D. (2016). Can you learn to teach programming in two days? I Proceedings of the Australasian Computer Science Week Multiconference, ACM, 16. doi:10.1145/2843043.2843063

Hallström, J. (2018). Ett forskningsfält i tillväxt. Teman i svensk teknikdidaktisk forskning. I K. Stolpe, G. Höst \& J. Hallström (Red.), Teknikdidaktisk forskning för lärare. Bidrag från en forskningsmiljö. (s.7793). Naturvetenskapernas och teknikens didaktik, 2.

Highfield, K. (2010). Robotic toys as a catalyst for mathematical problem solving. Australian Primary Mathematics Classroom, 15, 22-27.

Highfield, K., Mulligan, J., \& Hedberg, J. (2008). Early mathematics learning through exploration with programmable toys. I O. Figueras, J. L. Cortina, S. Alatorre, T. Rojano, \& A. Sepulveda (Red.), Proceedings of The joint meeting of Pme 32 and Pme-Na Xxx, Vol 3 (s.169-176). Mexico: Cinvestav-UMSNH.

Hsieh, H.-F. \& Shannon, S., H. (2005). Three approaches to qualitative content analysis. Qualitative Health Research, 15(9) 1277-1288. doi:10.1177/1049732305276687

Janka, P. (2008). Using a programmable toy at preschool age: why and how. Proceedings of SIMPAR, 112121.

Johansson, A.-M., \& Wickman, P.-O. (2011). A pragmatist understanding of learning progressions. I B. Hudson \& M. A. Meyer (Red.), Beyond fragmentation: Didactics, learning and teaching, (s.47-59). Leverkusen: Barbara Budrich Publishers.

Kazakoff, E.R., Sullivan, A., \& Bers, M.U. (2013). The effect of a classroom-based intensive robotics and programming workshop on sequencing ability in early childhood. Early Childhood Education Journal, 41(4), 245-255. doi:10.1007/s10643-012-0554-5

Kjällander, S., Åkerfeldt, A. \& Petersen, P. (2016). Översikt avseende forskning och erfarenheter kring programmering i förskola och grundskola. Stockholm: Stockholms universitet.

Klasander, C. (2010). Talet om tekniska system: Förväntningar, traditioner och skolverkligheter. Diss. Norrköping: Linköpings universitet 
Kurebayashi, S., Kamada, T., Kanemune, S., \& Kuno, Y. (2007). The Effect of Learning Programming with Autonomous Robots for Elementary School Students. I 11th European Logo Conference, Bratislava, (s. 1-9). Comenius University Press, Bratislava.

Lye, S. Y., \& Koh, J. H. L. (2014). Review on teaching and learning of computational thinking through programming: What is next for K-12? Computers in Human Behavior, 41, 51-61. doi:10.1016/j. chb.2014.09.012

Manches, A., \& Plowman, L. (2017). Computing education in children's early years: A call for debate. British Journal of Educational Technology, 48(1), 191-201. doi: 10.1111/bjet.12355

Misirli, A., \& Komis, V. (2014). Robotics and programming concepts in early childhood education: A conceptual framework for designing educational scenarios. I C., Karagiannidis, P., Politis \& I., Karasavvidis (Red.), Research on e-Learning and ICT in Education (s.99-118). Springer, New York, NY. doi: 10.1007/978-1-4614-6501-0_8

Newhouse, C.P., Cooper, M., \& Cordery, Z. (2017). Programmable toys and free play in early childhood classrooms. Australian Educational Computing, 32(1), 199-212.

Robins, A., Rountree, J., \& Rountree, N. (2003). Learning and Teaching Programming: A Review and Discussion. Computer Science Education, 13(2), 137-172. doi: 10.1076/csed.13.2.137.14200

Rolandsson, L. (2015). Programmed or Not. A study about programming teachers'beliefs and intentions in relation to curriculum. Diss. Stockholm: Kungliga Tekniska högskolan.

Sáez-Lopéz, J-M., Román-González, M., \& Vázquez-Cano, E. (2016). Visual programming languages integrated across the curriculum in elementary school: A two year case study using "Scratch" in five schools. Computers \& Education, 97, 129-141. doi: 10.1016/j.compedu.2016.03.003

Skolverket (2018). Läroplan för grundskolan, förskoleklassen och fritidshemmet 2011: reviderad 2018. Stockholm: Skolverket.

Sorva, J. (2012). Visual program simulation in introductory programming education. Diss. Helsingfors: Aalto univsersitet.

Yukselturk, E. \& Altiok, S. (2016). An investigation of the effects of programming with Scratch on the preservices IT teachers' self-efficacy perceptions and attitudes towards computer programming. British Journal of Educational Technology, 48(3), 789-801. doi:10.1111/bjet.12453

Zaharija, G., Mladenović, S., \& Boljat, I (2013). Introducing basic programming concepts to elementary school children. Procedia-Social and Behavioral Sciences, 106, 1576-1584. doi:10.1016/j.sbspro.2013.12.178 